\title{
Determination of the treatment period of banana seedlings with rhizobacteria in the control of Meloidogyne javanica
}

\author{
Pollyanna Santiago Lopes ${ }^{1}$, Regina Cássia Ferreira Ribeiro ${ }^{2}$, Adelica Aparecida Xavier ${ }^{3}$, \\ Leandro de Souza Rocha ${ }^{4}$, Edson Hiydu Mizobutsi² \\ Abstract- The introduction of rhizobacteria to the soil can be done via treatment of propagating \\ materials. The aim of this work was to evaluate in greenhouse the influence of immersion periods \\ of micropropagated 'Prata-Anã' banana seedling roots in suspension of different rhizobacterial \\ isolates on the growth of seedlings and control of Meloidogyne javanica. The experiment was set \\ up in greenhouse in a randomized block design in a $10 \times 2$ factorial scheme (rhizobacteria isolates) \\ $\mathrm{x}$ (immersion periods: 60 and 120 minutes) with 10 replicates. The additional treatment (control) \\ was composed of seedlings without any treatment infected with $M$. javanica. Treated seedlings were \\ planted in pots containing soil: previously autoclaved sand. After twenty-four hours, suspension \\ containing 3,000 M. javanica eggs was added to the soil. At 60 days, number of galls, egg mass \\ and eggs per root system, number of second-stage juveniles (J2) per $100 \mathrm{~cm}^{3}$ of soil were evaluated \\ and the reproduction factor was calculated. Shoot dry matter mass was also evaluated. Of the four \\ rhizobacteria that reduced the reproductive capacity of the nematode, three were more efficient when \\ seedlings were treated for 120 minutes. The treatment period of banana seedlings did not affect the \\ shoot dry matter yield and all rhizobacteria increased the dry matter weight of seedlings infected \\ with Meloidogyne javanica. It could be concluded that rhizobacteria have different treatment time \\ requirements for seedlings to control the nematode, but do not interfere with the development of \\ seedlings. \\ Index terms: Musa sp., microbiolization, Paenibacillus sp., Bacillus spp., Root-knot nematode.

\section{Determinação do período de tratamento de mudas de bananeira com rizobactérias no controle de Meloidogyne javanica}

\section{Corresponding author:}

Received: Janeiro 03, 2017. Accepted : October 02, 2017.

Copyright: All the contents of this journal, except where otherwise noted, is licensed under a Creative Commons Attribution License.

\section{(cc) $\mathrm{EY}$}

Resumo- Aintrodução de rizobactérias ao solo pode ser feita via tratamento de materiais propagativos. O objetivo deste trabalho foi avaliar, em casa de vegetação, a influência de períodos de imersão de raízes de mudas de bananeira 'Prata-Anã' micropropagadas, em suspensão de diferentes isolados de rizobactérias no crescimento de mudas e no controle de Meloidogyne javanica. O experimento foi montado em casa de vegetação, em delineamento em blocos ao acaso, em esquema fatorial 10 (isolados de rizobactérias) x 2 (períodos de imersão: 60 e 120 minutos), com 10 repetições. $\mathrm{O}$ tratamento adicional (testemunha) foi composto por mudas sem nenhum tratamento, infectadas com $M$. javanica. As mudas tratadas foram plantadas em vasos contendo solo: areia previamente autoclavados. Após vinte e quatro horas, suspensão contendo 3.000 ovos de M.javanica foi adicionada ao solo. Aos 60 dias, avaliaram-se: número de galhas, de massas de ovos e de ovos por sistema radicular, número de juvenis de segundo estádio (J2) por $100 \mathrm{~cm}^{3}$ de solo e calculou-se o fator de reprodução. Avaliou-se também a massa de matéria seca da parte aérea. Das quatro rizobactérias que reduziram a capacidade reprodutiva do nematoide, três foram mais eficientes quando as mudas foram tratadas por 120 minutos. O período de tratamento das mudas de bananeira não afetou a produção de matéria seca da parte aérea e todas rizobactérias aumentaram o peso da matéria seca de mudas infectadas com Meloidogyne javanica. Conclui-se que as rizobactérias têm requerimentos diferentes de tempo de tratamento de mudas para controlarem o nematoide, mas não interferem no desenvolvimento das mudas.

Termos para indexação: Musa sp., microbiolização, Paenibacillus sp., Bacillus spp., nematoide das galhas.

${ }^{1}$ Agronomist. Dsc. Plant Production-UENF / CCTA-Campos dos Goytacases, RJ, CEP: 28013-602. Part of the Master's Dissertation of the first author of UNIMONTES. Financial Support: FAPEMIG / CAPES.Email: pollyannasantiago@yahoo.com.br

${ }^{2}$ Agronomist. Dsc. Phytopathology, Professor at the Department of Agrarian Sciences. UNIMONTES. BIPDT / FAPEMIG scholarship. Caixa Postal 91, CEP: 39440-000. Janaúba, MG. Email: regina.ribeiro@unimontes.br, adelica@unimontes.br, edson.mizobutsi@unimontes.br ${ }^{3}$ Agronomist. Dsc. Agricultural Sciences - EMBRAPA Cassava and Fruits analyst, Cruz das Almas, BA, 44380-000 . Email: leandro.rocha@ embrapa.br 


\section{Introduction}

The planting of micropropagated banana seedlings is an excellent strategy in the cultivation system. They exhibit genetic uniformity (ALVES et al., 2004) and absence of insects and pathogens such as Fusarium oxysporum f. sp. cubense, which causes Panama Disease and plant parasitic nematodes such as Radopholus similis and species of the genus Meloidogyne. Such pathogens may be limiting to cultivation. Seedlings produced from tissue culture may, however, be more susceptible to fungi and nematodes when transplanted to the field than seedlings produced in the traditional manner, in view of the elimination of the beneficial microbiota associated with traditional seedlings (LAZAROVITS; NOWAK, 1997). Therefore, a possible strategy to minimize such problems is the use of rhizobacteria in the treatment of roots of micropropagated seedlings. This strategy can reduce the population of some pathogens that parasitize the plant root system, such as phytonematodes, and also increase the development of plants.

Rhizobacteria have several mechanisms of biological control and increase in the development of plants, such as the production of growth hormones, siderophores and antibiotics. These bacteria have an additional advantage over other soil microorganisms, as they are widely distributed in the rhizosphere, which confirms their ability to establish themselves in relation to other microorganisms. Most rhizobacteria belong to genera Pseudomonas and Bacillus. Bacteria of the genus Bacillus also have favorable characteristics for inoculant production, since they produce endospores that are spores highly resistant to extremes of temperature, radiation, chemical agents and time and have long shelf life (LIU et al., 2016). The development of micropropagated eucalyptus, kiwi and potato seedlings and control of nematodes have been obtained by the application of rhizobacteria (MAFIA et al., 2009; ERTURK et al., 2010, TKACHENKO et al., 2017, XIANG et al., 2017).

The literature shows a variation regarding the time of treatment of seedlings with rhizobacteria in the control of phytopathogens and the promotion of plant development. As an example, it was observed that immersion of bean and cowpea seeds in bacterial suspensions of Bacillus spp. for 48 hours provided increased plant growth and control of M. javanica (DAWAR et al., 2008). Souza Júnior et al. (2010) found that immersion of rice seeds for 30 minutes under agitation in bacterial suspensions of rhizobacteria isolated from rice cultivation also promoted plant growth and control of M. graminicola. In another study, the selection of 45 rhizobacteria isolates was carried out in greenhouse recorded 10 isolates that stood out in the control of M. javanica and Panama Disease by treating seedlings for 5 minutes (Ribeiro et al., 2012). It is believed that with longer contact time between bacteria and the root system, rhizosphere colonization may be more efficient.

Thus, the aim of this work was to evaluate the influence of immersion periods of micropropagated seedling roots of 'Prata-Anã' banana in suspension of rhizobacteria isolates on seedling growth and control of M. javanica.

\section{Material and Methods}

The experiment was conducted in the laboratory. Ten rhizobacteria isolates from 'Prata-Anã' banana trees from different municipalities in northern Minas Gerais were used. Bacteria were identified by the fatty acid profile test by gas chromatography (SANHUEZA; MELO, 2007) at the Laboratory of Environmental Microbiology - National Center for Environmental Research of the Brazilian Agricultural Research Corporation (Embrapa). Bacteria kept in TSA medium (Trypic-Soy-Agar) at $-4^{\circ} \mathrm{C}$ (MARIANO et al., 2000) were subcultured into Petri dishes containing TSA medium and incubated at $28^{\circ} \mathrm{C}$ for 48 hours. Subsequently, in a laminar flow chamber, they were subcultured with a platinum loop into erlenmeyers containing $100 \mathrm{~mL}$ of Trypic Soy Broth (TSB) medium, being taken to the orbital shaker where they remained for 48 hours at $28^{\circ} \mathrm{C}$ under constant stirring at $150 \mathrm{rpm}$. After this period, cultures were centrifuged at 10,000 rpm for 15 minutes and the supernatant was discarded. Then, saline $(0.85 \% \mathrm{NaCl})$ was added to bacterial cells retained at the bottom of each tube and the suspension obtained was calibrated in spectrophotometer for OD ${ }_{540}$ $=0.5$ absorbance.

'Prata-Anã' banana seedlings produced 30 days after cultivation in rooting medium (completely rooted with three leaves released and at least five centimeters high) from the Laboratory of Biotechnology in the sixth subculture, had their root systems washed in water. Seedlings were then transferred to erlenmeyers containing bacterial suspension calibrated to $\mathrm{A}_{540}=0.5$ and submitted to constant stirring at $200 \mathrm{rpm}$ for two periods (60 and 120 minutes). They were then transferred to tubes containing Plantmax ${ }^{\circledR}$ substrate where they remained for 30 days in a nursery with controlled irrigation and sombrite. After the acclimatization phase, they were transplanted to 3 L plastic vessels containing substrate composed of soil: sand (2: 1) autoclaved for three consecutive days. The assay was assembled in greenhouse in a randomized block design in the following factorial scheme: 10 (rhizobacteria isolates) x 2 (immersion periods) with nine replicates. Control (additional treatments) was composed of plants not inoculated with rhizobacteria and inoculated with $M$. javanica. Irrigation was performed manually, according to the water requirement.

After 60 days, shoot dry matter weight (pseudostalk + leaves) was evaluated. For that, the shoot was cut at the height of the plant colon, dried in oven under forced 
ventilation at $65^{\circ} \mathrm{C}$ for 72 hours and then weighed in analytical scale. For the nematological evaluations, the root system was removed and washed in water. Next, egg masses of nematodes in the root systems were stained with floxin B (TAYLOR; SASSER, 1978). After staining, the number of egg masses and galls per root system were quantified. For quantification of the number of eggs, extraction was performed according to the Hussey and Barker (1973) technique modified by Boneti and Ferraz (1981). In an inverted objective optical microscope, the number of $M$. javanica eggs per root system was quantified. The number of second-stage juveniles $\left(\mathrm{J}_{2}\right)$ per $100 \mathrm{~cm}^{3}$ of soil was evaluated after soil extraction by means of the Jenkins technique (1964). The reproduction factor (RF) was obtained by means of the formula $\mathrm{RF}=$ $\mathrm{Pf} / \mathrm{Pi}$, where $\mathrm{Pf}$ is the number of eggs at 60 days and $\mathrm{Pi}$ the number of eggs used in soil infestation.

The results were submitted to analysis of variance by the Sisvar software (FERREIRA, 2011) and the means compared by the Scott-Knott test at 5\% probability. The control mean was compared with the other treatments by the Dunnett test at 5\% probability.

\section{Results and Discussion}

The shoot dry matter mass was influenced by the interaction between bacterial isolates and immersion periods $(p \leq 0.05)$. All rhizobacteria increased the dry matter weight in relation to control and did not differ from each other. The increase ranged from $16.88 \%$ (B. pumilus-60) to $25.58 \%$ (B. pumilus-1) (Table 1). This demonstrates that increasing contact time between bacteria and roots is important for plant development. Several authors have verified promotion of plant growth, such as cotton with different species of Bacillus (Xiang et al., 2017), eucalyptus with B. subtilis (MAFIA et al., 2009), onion with Pseudomonas spp. and B. cereus (HARTHMANN et al., 2009), kiwi with Bacillus, B. simplex and Comamonas acidovorans (ERTURK et al., 2010).

Greater development of plants by Bacillus spp. may be due, in part, to the production of plant phytoregulators (ARAÚJO et al., 2005). Rhizobacteria are capable of synthesizing substances such as gibberellins and indoleacetic acid in vitro and in the rhizosphere of plants. Khalmi et al. (2017) observed that the application of five rhizobacteria isolates producing AIA in soybean increased plant growth rate, leaf size, leaf chlorophyll content, root and shoot dry matter weight and number of pods per plant compared to uninoculated plants. In addition to hormones, some rhizobacteria are phosphate solubilizers and nitrogen fixers (ZAHID et al., 2015).

Regarding the period of root immersion in the rhizobacteria suspension, it was verified that, regardless of isolate, both treatment periods of roots promoted higher shoot dry matter weight when compared to control (Table
2). There are no studies comparing different time periods in the microbiolization of banana seedlings.

There was a significant effect of rhizobacteria applied to roots at different times on the number of galls, egg masses, eggs, J2, RF as compared to control (Table 3 , Table 4). In the 120-minute period, the reduction in the number of galls provided by P. lentimorbus- 69 was $61.33 \%$ in relation to control and at 60 minutes, the same bacterium promoted reduction of $55.52 \%$ in relation to control (Table 3). It was verified that B. pumilus- $1, B$. pumilus- 10, B. pumilus-76, $P$. lentimorbus -17 and $P$. lentimorbus- 69 bacteria reduced the number of galls per root system, in the time of 120 minutes, in relation to the other bacteria. However, in the 60-minute time period, B. pumilus -1 and P. lentimorbus -69 bacteria presented higher number of galls when compared to the others (Table 3 ). There was a significant interaction between bacterial isolates and time periods for the following variables: number of galls, number of egg masses, number of eggs per root system, number of $\mathrm{J} 2$ of M. javanica per $100 \mathrm{~cm}^{3}$ of soil and reproduction factor. By fixing factor isolates, it was observed that P. lentimorbus- 69 and B. pumilus-1 bacteria promoted lower number of galls when seedling roots were immersed for 120 minutes. The reduction caused by $P$. lentimorbus -69 was $55.5 \%$ in relation to immersion of seedlings in the suspension of the same bacterium for 60 minutes. P. lentimorbus-24 reduced the same variable by $27.8 \%$ when root immersion lasted 60 minutes (Table 3 ).

All isolates differed from control and reduced the number of egg masses per root system in both periods. At the 120-minute immersion time, P. lentimorbus-69 and B. pumillus -1 bacteria showed reduction of $73 \%$ and $69.93 \%$ in relation to control. In the 60 -minute time period, reduction of $70.98 \%$ and $65.90 \%$ was observed for P. lentimorbus-69 and P. lentimorbus-17 bacteria, respectively, relative to control (Table 3 ). In the comparison among isolates in the 120-minute time period, P. lentimorbus -17 , P. lentimorbus-69, B. pumilus -1 and Bacillus sp.-36 bacteria caused fewer egg masses per root system. In the 60-minute time period, $P$. lentimorbus -69, B. pumilus-76, P. lentimorbus 17, Bacillus sp.-36, B. subtilis $34, B$. pumilus -3 and B. pumilus-60 were those that promoted smaller number of this variable when compared to the other isolates. In the period of time within each isolate, it was observed that there was no significant effect of the immersion period of seedlings, except for $P$. lentimorbus-69, which reduced the number of egg masses by $44.3 \%$ when seedlings were immersed for 120 minutes compared to the 60-minute time period (Table 3).

In relation to the number of eggs per root system, it was observed that in the 120 -minute time period, $B$. pumilus-76, B. subtilis-34 and P. lentimorbus-69 bacteria reduced in $60.33 \%, 59.96 \%$ and $56.27 \%$ in relation to control. These bacteria also reduced the number of 
eggs when compared to other bacteria. In the 60-minute immersion period, B. pumilus-76 reduced the number of eggs by $48.15 \%$ compared to control and also differed from the other bacteria (Table 4). In the time within each isolate, B. pumilus-10, B. subtilis-34 and P. lentimorbus-69 bacteria were found to have reduced by $27.90 \%, 43 \%$ and $41.79 \%$ respectively, number of eggs in the 120 -minute immersion time in relation to the 60 -minutes immersion time. However, B. pumilus-3, P. lentimorbus-24 and Bacillus sp.-36 were more efficient when they were in contact with roots for 60 minutes and reduced by $16.41 \%$, $12.5 \%$ and $19.55 \%$, respectively, over the 120-minute immersion time (Table 4).

Treatment of seedlings with $P$. lentimorbus-69, B. pumilus-76, P. lentimorbus-17, B. pumilus-1 and $B$. pumilus-10 for 120 minutes reduced the number of $\mathrm{J} 2$ of $M$. javanica in relation to control. Of these isolates, B. pumilus-10 showed reduction of $69.60 \%$. When seedlings were treated for 60 minutes, B. pumilus -76 and B. subtilis-34 reduced the number of $\mathrm{J} 2$ by $52.30 \%$ and $39.64 \%$ relative to control (Table 3). P. lentimorbus-69, B. pumilus-1, P. lentimorbus-17, B. pumilus-3 and $P$. lentimorbus -24 caused lower number of $\mathrm{J} 2$ of $M$. javanica when treatment of seedlings occurred for 120 minutes compared to the 60-minute period. Immersion of roots in the P. lentimorbus-69 suspension for 120 minutes caused a reduction of $49.80 \%$ in the number of $\mathrm{J} 2$ of $M$. javanica when compared to the immersion of seedlings for 60 minutes. However, B. subtilis-34 reduced by $30.53 \%$ the same variable when root immersion occurred for 60 minutes (Table 3).

Treatment of seedlings with $B$. pumilus-76, B. subtilis-34, P. lentimorbus-69 and B. pumilus-10 for 120 minutes reduced the reproductive factor by $60.34 \%$, $60.12 \%, 56.38 \%$ and $43.60 \%$, respectively, in relation to control. In the treatment of seedlings for 60 minutes, $B$. pumilus -76 reduced the reproductive factor by $48.29 \%$ in relation to control. Bacillus sp.-36, B. subtilis-34, $P$. lentimorbus-69 and B. pumilus-1 differed from control, reducing by $33.33 \%, 31.46 \%, 23.36 \%$ and $20.24 \%$, respectively. Only B. pumilus-76 showed difference from the other bacteria, showing superior reduction of this variable (Table 4). In the time within each isolate, B. subtilis-34, P. lentimorbus-69, B. pumilus-10, reduced the reproduction factor when seedlings were immersed in bacterial suspensions for 120 minutes, with reductions of $41.8 \%, 43 \%$ and $28.20 \%$, respectively. However, Bacillus sp.-36, B. pumilus-3 and P. lentimorbus-24 reduced the reproduction factor in the 60 -minute immersion period (Table 4).

Considering the reproductive capacity of $M$. javanica represented by variable RF, it was observed that among the four bacteria that reduced this variable in relation to control, P. lentimorbus-69, B. pumilus-10 and B. subtilis-34, with 120-minute immersion time, stood out in the control of $M$. javanica. The control of several Meloidogyne species with different rhizobacteria species have been reported by several authors (DAWAR et al., 2008, LEE and KIM, 2015, CHINEYE et al., 2017). The control of nematodes by rhizobacteria can be explained by the direct action of these bacteria on the $M$. javanica population through the production of antibiotics and toxic metabolites or by the indirect action through the modification of root exudates, affecting the development of each stage of the nematode life cycle (LUDWIG et al., 2013).

Regarding the effect of the immersion time of seedlings on the bacterial suspension, it was observed that in general, within 120 minutes, there was greater reduction of almost all variables. This can be explained by the longer contact time of roots with the bacterial cells, which may have increased the number of cells adhered to the roots and, thus, higher production of antibiotics and metabolites that have effect on $M$. javanica. In the work of Ribeiro et al. (2012) in which seedlings were treated for 5 minutes with the same bacteria, there was no reduction in the number of egg masses, eggs and RF, demonstrating the need for longer immersion period.

In this work, variable results among isolates of the same species in the control of $M$. javanica were observed. This fact can be explained by the occurrence of intraspecific variability. It is important to point out that the isolates tested were from 'Prata-Anã' banana tree rhizosphere from different municipalities in northern Minas Gerais. According to Schloter et al. (2000), several factors may influence intraspecific diversity, such as spatial separation, environmental differences, and host-bacterial interactions. Similar results were obtained by Oliveira et al. (2007), who observed that a few B. pumilus isolates reduced the number of galls and $M$. exigua eggs in relation to control, while others did not. Likewise, Carvalho et al. (2009) verified that some B. pumilus isolates increased the length of wheat coleoptile and others did not. Xiang et al. (2017) verified variability among different isolates of several Bacillus species on the in vitro mortality of $M$. incognita juveniles and on the number of egg masses of the nematode and cotton height and biomass under greenhouse conditions.

Intraspecific variability has been found in bacteria (JONGHE et al., 2007; MANZANO et al., 2009). Manzano et al. (2009) verified by means of RAPD / PCR molecular methods, high intraspecific variability of $B$. cereus and $B$. thurigiensis. 
Table 1. Average shoot dry matter weight (SDMW) of 'Prata-Anã' banana seedlings treated with different rhizobacterial isolates and inoculated with Meloidogyne javanica.

\begin{tabular}{lc}
\hline \multicolumn{1}{c}{ Isolates } & SDMW (g) \\
\hline Paenibacillus lentimorbus-17 & $7,85 \mathrm{a}^{*}$ \\
Paenibacillus lentimorbus-24 & $8,15 \mathrm{a}^{*}$ \\
Bacillus pumilus-3 & $8,35 \mathrm{a}^{*}$ \\
Bacillus pumilus-76 & $8,20 \mathrm{a}^{*}$ \\
Bacillus subtilis -34 & $7,95 \mathrm{a}^{*}$ \\
Bacillus sp.-36 & $7,75 \mathrm{a}^{*}$ \\
Paenibacillus lentimorbus-69 & $8,05 \mathrm{a}^{*}$ \\
Bacillus pumilus-10 & $7,55 \mathrm{a}^{*}$ \\
Bacillus pumilus-1 & $7,70 \mathrm{a}^{*}$ \\
Bacillus pumilus-60 & $8,65 \mathrm{a}^{*}$ \\
\hline VC (\%) & 13,20 \\
\hline Control & 6,40 \\
\hline
\end{tabular}

Averages followed by the same letter do not differ among themselves by the Scott-Knott test (1974) at 5\% probability level. * Significant by the Dunnett test at $5 \%$ probability, in the column, for control.

Tabela 2. Average shoot dry matter weight (SDMW) of 'Prata-Anã' banana seedlings treated with rhizobacterial isolates by two immersion periods two months after cultivation.

\begin{tabular}{lc}
\hline Period & SDMW $(\mathrm{g})$ \\
\hline 120 & $7,96 \mathrm{a}^{*}$ \\
60 & $8,08 \mathrm{a}^{*}$ \\
\hline VC $(\%)$ & 13,20 \\
\hline Control & 6,40 \\
\hline
\end{tabular}

Averages followed by the same letter do not differ from each other by the F test at 5\%.* Significant by the Dunnett test at $5 \%$ probability, in the column, for control.

Table 3. Mean number of galls and egg masses and second-stage juveniles (J2) of Meloidogyne javanica by root system of 'Prata-Anã' banana plants, immersed in suspensions of different rhizobacteria isolates in different immersion periods after 60 days of cultivation.

\begin{tabular}{|c|c|c|c|c|c|c|}
\hline \multirow[t]{2}{*}{ Isolados } & \multicolumn{2}{|c|}{ Galls } & \multicolumn{2}{|c|}{ Egg masses } & \multicolumn{2}{|c|}{$J 2 / 100 \mathrm{~cm}^{3}$ soil } \\
\hline & $120^{\prime}$ & $60^{\prime}$ & $120^{\prime}$ & $60^{\prime}$ & 120 & 60 \\
\hline Bacillus lentimorbus-69 & $178,70 \mathrm{aA}^{*}$ & $206,80 \mathrm{aA}^{*}$ & $15,40 \mathrm{aA}^{*}$ & $16,60 \mathrm{aA}^{*}$ & $33,90 \mathrm{bA}^{*}$ & $67,50 \mathrm{bB}$ \\
\hline \multirow{3}{*}{$\begin{array}{l}\text { Bacillus pumilus- } 76 \\
\text { Paenibacillus lentimorbus- } \\
17 \\
\text { Bacillus pumilus-1 }\end{array}$} & $192,70 \mathrm{aA}^{*}$ & $277,70 \mathrm{bA}^{*}$ & $22,50 \mathrm{bA}^{*}$ & $21,60 \mathrm{aA}^{*}$ & $40,00 \mathrm{bA}^{*}$ & $32,00 \mathrm{aA}^{*}$ \\
\hline & $212,10 \mathrm{aA}^{*}$ & $287,70 \mathrm{bA}^{*}$ & $20,80 \mathrm{bA}^{*}$ & $19,50 \mathrm{aA}^{*}$ & $43,30 \mathrm{bA}^{*}$ & $67,70 \mathrm{bB}$ \\
\hline & $225,90 \mathrm{aA} *$ & $401,50 \mathrm{cB}^{*}$ & $17,20 \mathrm{aA}^{*}$ & $30,90 \mathrm{cB}^{*}$ & $40,70 \mathrm{bA}^{*}$ & $64,60 \mathrm{bB}$ \\
\hline Bacillus pumilus-10 & $258,10 \mathrm{aA}^{*}$ & $352,90 \mathrm{cB}^{*}$ & $21,70 \mathrm{bA}^{*}$ & $24,80 \mathrm{bA}^{*}$ & $20,40 \mathrm{aA}^{*}$ & $50,20 \mathrm{bA}^{*}$ \\
\hline Bacillus. sp- 36 & $277,40 \mathrm{bA}^{*}$ & $237,30 \mathrm{aA}^{*}$ & $19,80 \mathrm{aA}^{*}$ & $23,00 \mathrm{aA}^{*}$ & $71,10 \mathrm{dA}$ & $60,20 \mathrm{bA}$ \\
\hline Bacillus subtilis-34 & $317,60 \mathrm{bA}^{*}$ & $205,60 \mathrm{aA}^{*}$ & $23,00 \mathrm{bA}^{*}$ & $20,40 \mathrm{aA}^{*}$ & $58,30 \mathrm{cB}$ & $40,50 \mathrm{aA}^{*}$ \\
\hline Bacillus pumilus- 3 & $279,80 \mathrm{bA}^{*}$ & $235,70 \mathrm{aA}^{*}$ & $23,70 \mathrm{bA}^{*}$ & $21,20 \mathrm{aA} *$ & $53,80 \mathrm{cA}$ & $76,60 \mathrm{cB}$ \\
\hline \multirow{2}{*}{$\begin{array}{l}\text { Bacillus pumilus }-60 \\
\text { Paenibacillus lentimorbus- } \\
24\end{array}$} & $298,60 \mathrm{bA} *$ & $285,70 \mathrm{bA}^{*}$ & $23,00 \mathrm{bA}^{*}$ & $21,30 \mathrm{aA}^{*}$ & $82,10 \mathrm{dA}$ & $84,30 \mathrm{cA}$ \\
\hline & $402,90 \mathrm{cB}^{*}$ & $292,60 \mathrm{bA}^{*}$ & $29,60 \mathrm{cA}^{*}$ & $24,70 \mathrm{bA}^{*}$ & $57,90 \mathrm{cA}$ & $82,90 \mathrm{cB}$ \\
\hline Mean & 264,38 & 278,35 & 20,87 & 22,4 & 50,15 & 62,65 \\
\hline F (isolates x period) & \multicolumn{2}{|c|}{$8,71^{* *}$} & \multicolumn{2}{|c|}{$3,57^{* *}$} & \multicolumn{2}{|c|}{$5,09 * *$} \\
\hline $\mathrm{VC}(\%)$ & \multicolumn{2}{|c|}{26,74} & \multicolumn{2}{|c|}{28,05} & \multicolumn{2}{|c|}{33,49} \\
\hline Control & \multicolumn{2}{|c|}{462,20} & \multicolumn{2}{|c|}{57,20} & \multicolumn{2}{|c|}{67,10} \\
\hline
\end{tabular}

Means followed by the same lowercase letter in the column do not differ from one another by the Scott-Knott test (1974) and averages followed by the same capital letter on the row (within the same variable) do not differ significantly from each other by the 5\% F-test.

* Significant by the Dunnett test at 5\% probability in the column for control. ** Significant interaction between bacterial isolates and time periods. 
Table 4. Mean of the reproduction factor (RF) and number of Meloidogyne javanica eggs per root of 'Prata-Anã' banana seedlings immersed in suspensions of different rhizobacterial isolates at different immersion periods after 60 days in greenhouse.

\begin{tabular}{|c|c|c|c|c|}
\hline \multirow[t]{2}{*}{ Isolados } & \multicolumn{2}{|c|}{ Fator de reprodução } & \multicolumn{2}{|c|}{ Número de ovos/raiz } \\
\hline & 120 & 60 & 120 & 60 \\
\hline Bacillus pumilus- 76 & $1,27 \mathrm{aA}^{*}$ & $1,66 \mathrm{aA}^{*}$ & $3820,10 \mathrm{aA}^{*}$ & $4993,30 \mathrm{aA}^{*}$ \\
\hline Bacillus subtilis-34 & $1,28 \mathrm{aA}^{*}$ & $2,20 \mathrm{bB}^{*}$ & $3856,20 \mathrm{aA}^{*}$ & $6625,70 \mathrm{bB}^{*}$ \\
\hline Paenibacillus lentimorbus-69 & $1,40 \mathrm{aA}^{*}$ & $2,46 \mathrm{bB}$ & $4212,70 \mathrm{aA}^{*}$ & $7389,40 \mathrm{cB}^{*}$ \\
\hline Bacillus pumilus-10 & $1,96 \mathrm{bA}^{*}$ & $2,73 \mathrm{cB}$ & $5908,10 \mathrm{bA}^{*}$ & $8195,40 \mathrm{cB}$ \\
\hline Paenibacillus lentimorbus- 17 & $2,48 \mathrm{cA}$ & $2,63 \mathrm{cA}$ & $7469,03 \mathrm{cA}^{*}$ & $7916,20 \mathrm{cA}$ \\
\hline Bacillus. sp- 36 & $2,66 \mathrm{cB}$ & $2,14 \mathrm{bA}^{*}$ & $8004,20 \mathrm{cB}$ & $6438,90 \mathrm{bA}^{*}$ \\
\hline Bacillus pumilus-1 & $2,73 \mathrm{cA}$ & $2,56 \mathrm{cA}^{*}$ & $8193,60 \mathrm{cA}$ & $7691,00 \mathrm{cA}^{*}$ \\
\hline Bacillus pumilus- 3 & $3,36 \mathrm{~dB}$ & $2,81 \mathrm{cA}$ & $10108,90 \mathrm{~dB}^{*}$ & $8449.80 \mathrm{cA}$ \\
\hline Bacillus pumilus -60 & $2,73 \mathrm{cA}$ & $3,02 \mathrm{dA}$ & $8207,50 \mathrm{cA}$ & $9066,70 \mathrm{dA}$ \\
\hline Paenibacillus lentimorbus- 24 & $3,78 \mathrm{~dB}^{*}$ & $3,30 \mathrm{dA}$ & $11344,80 \mathrm{~dB}^{*}$ & $9926,70 \mathrm{dA}$ \\
\hline Mean & 2,36 & 2,55 & 7112,51 & 7669,31 \\
\hline $\mathrm{F}$ (isolados $\mathrm{x}$ period) & \multicolumn{2}{|c|}{$6,76 * *$} & \multicolumn{2}{|c|}{$6,76^{* *}$} \\
\hline $\mathrm{VC}(\%)$ & \multicolumn{2}{|c|}{21,13} & \multicolumn{2}{|c|}{21,13} \\
\hline Control & \multicolumn{2}{|c|}{3,211} & \multicolumn{2}{|c|}{9631,30} \\
\hline
\end{tabular}

Means followed by the same lowercase letter in the column do not differ from one another by the Scott-Knott test (1974) and averages followed by the same capital letter on the row (within the same variable) do not differ significantly from each other by the 5\% F-test.

* Significant by the Dunnett test at 5\% probability, in the column, for control. ** Significant interaction between factors, bacterial isolates and time periods.

\section{Conclusions}

All rhizobacteria increased the dry matter weight of 'Prata-Anã' banana seedlings infected with Meloidogyne javanica.

The time of treatment by rhizobacteria of banana seedlings infected by $M$. javanica did not affect shoot dry matter production.

Bacteria B. pumilus -10 , Bacillus sp.-34, P. lentimorbus-69 reduced the reproduction of $M$. javanica in 'Prata-Anã' banana plants treated for 120 minutes.

Bacillus sp.-36 reduced the reproduction of $M$. javanica in 'Prata-Anã' banana plants treated for 60 minutes.

\section{Acknowledgments}

The authors thank FAPEMIG (Minas Gerais State Foundation for Research Development) for the financial support and research grant.

\section{References}

ALVES, E.J.; LIMA, M.B.; SANTOS-SEREJO, A.S.; TRINDADE, A.V.Propagação.In: BORGES, A.L.; SILVA, L.S. O cultivo da bananeira. Cruz das Almas: Embrapa Mandioca e Fruticultura, 2004. p. 59-86.

ARAÚJO, F.F.; HENNING, A.; HUNGRIA, M. Phytohormones and antibiotics produced by Bacillus subtilis and their effects on seed pathogenic fungi and soybean root development. World Journal of Microbiology and Biotechnology, Oxford, v.21, n.8/9, p.1639-1645, 2005.

BONETI, J. I. S.; FERRAZ, S. Modificação do método de Hussey e Barker para extração de ovos de Meloidogyne exigua em raízes de cafeeiro. Fitopatologia Brasileira, Brasília, DF, v.6, n.1, p.553. 1981.

CARVALHO, D.D.C.; OLIVEIRA, D.F.; PASQUAL, M.; CAMPOS, V.P. Rizobactérias produtoras de promotores do crescimento de plantas. Pesquisa Agropecuária Tropical, Goiânia, v.39, n.4, p.338-341, 2009.

CHINHEYA, C.C.; YOBO, K.S.; LAING, M.D. Biological control of the rootknot nematode, Meloidogyne javanica (Chitwood) using Bacillus isolates on soybean. Biological Control, Orlando, v.109, p.37-41, 2017. 
DAWAR, S.; TARIQ, M.; ZAKI, M.J. Application of Bacillus species in control of Meloidogyne javanica (TREUB) Chitwood on cowpea and mash bean. Pakistan Journal of Botany, Karachi, v.40, n.1, p.439-444, 2008.

ERTURK, Y.; ERCISLI, S.; HAZNEDAR, A.; CAKMAKCI, R. Effects of plant growth promoting rhizobacteria (PGPR) on rooting and root growth of Kiwifruit (Actinidia deliciosa) stem cuttings. Biological Research, Santiago de Chile, v.43, n.1, p.91-98, 2010.

FERREIRA, D.F. Sisvar: a computer statistical analysis system. Ciência e Agrootecnologia, Lavras, v.35, n.6, p.1039-1042, 2011.

HARTHMANN, O. E. L.; MÓGOR, A.F.; WORDELL FILHO, A.; LUZ, W.C.; BIASI, L.A.Tratamento de sementes com rizobactérias na produção de cebola. Ciência Rural, Santa Maria, v.39, n.9, p.2533-2538, 2009.

JENKINS, W.R. A rapid centrifugal- flotation technique for separating nematodes from soil. Plant Disease Reporter, Washington, v.48, n.9, p.692. 1964

JONGHE, V.; COOREVITIS, A.; VANDROEMME, J.; HEYRMAN, J.; VOS, P.; HEYNDRICKX, M. Intraspecific genotypic diversity of Bacillus species from raw Milk. International Dairy Journal, Barking, v.18, n.5, p.496-505, 2008.

KHALMI, K.; NGURAH, D.; SUDANA, I.M.; WIRYA, I.G.N.A.S. Potential of indole acetic acid producing rhizobacteria to promote the growth and increase the yield of edamame, a vegetable soybean (Glycine max). International Journal of Pharma and Bio Sciences, Amsterdam, v.8, n.3, p.604-608, 2017.

LAZAROVITS, G.; NOWAK, J. Rhizobacteria for improvement of plant growth and establishment. HortScience, Alexandria, v.32, n.2, p.188-192, 1997.

LEE, Y.S.; KIM, K.Y. Antagonistic potential of Bacillus pumilus L1 against root-knot nematode, Meloidogyne arenaria. Journal of Phytopathology, Berlin, v.164, p.29-39, 2015.

LIU, S.L.; WU, W.J.; YUNG, P.T. Effect of sonic stimulation on Bacillus endospore germination. FEMS Microbiology Letters, Amsterdam, v.3633, n.1, p.1-7, 2016.
LUDWIG, J.; MOURAA.B.; GOMES, C.B. Potencial da microbiolização de sementes de arroz com rizobactérias para o biocontrole do nematoide das galhas. Tropical Plant Pathology, Brasília, DF, v.38, n.3, p.264-268, 2013.

MAFIA, R.G.; ALFENAS, A.C.; MAFFIA, L.A.; FERREIRA, E.M.; BINOTI, D.H.B.; SIQUEIRA, L. Microbiolização e interação entre rizobactérias promotoras do crescimento e clones de eucalipto. Revista Árvore, Viçosa, MG, v.33, p.789-797, 2009.

MANZANO, M.; GIUSTO, C.; LACUMIN, L.; ACNTONI, C.; COMI, G. Molecular methods to evaluate biodiversity in Bacillus cereus and Bacillus thuringiensis strains from different origins. Food Microbiology, London, v.26, n.3, p.259-264, 2009.

MARIANO, R.L.R.; MICHEREFF, S.J.; SILVEIRA, E.B.; ASSIS, S.M.P.; GOMES, A.M.A. Isolamento de bactérias para testes de antagonismo. In: MARIANO, R.L.R. (Coord.). Manual de práticas em fitobacteriologia. Recife: O autor, 2000. p.115-119.

OLIVEIRA, D.F.; CAMPOS, V.P.; AMARAL, D.R.; NUNES, A.S.; PANTALEÃO, J.A.; COSTA, D.A. Selection of rhizobacteria able to produce metabolites active against Meloidogyne exigua. European Journal Pathology, Dordrecht, v. 119, n.4, p. 477-479, 2007.

RIBEIRO, R.C.F.; CAMPOS, V.P.; XAVIER, A.A.; ROCHA, L.S.; RIBEIRO, H.B.; AGUIAR, F.M.; SOUZA, R.M.; MIZOBUTSI, E.H.; DIAS-ARIEIRA, C.R. Rizobactérias no controle de Meloidogyne javanica e mal do Panamá em bananeira. Nematropica, Bradenton, v. 42, n.2, 218-226, 2012.

SANHUEZA, R.M.V.B.; MELO, I.S. Identificação de bactérias por análise dos ácidos graxos. In: SANHUEZA, R.M.V.B; MELO, I.S. Métodos utilizados no biocontrole de fitopatógenos. Bento Gonçalves: Embrapa Uva e Vinho, 2007. p.59-65.

SCHLOTER, M.; LEBUHN, T.; HARTMANN, A. Ecology and evolution of bacterial microdiversity. FEMS Microbiology Reviews, Amsterdam, v.24, n.5, p.647-660, 2000.

SOUZA JÚNIOR, I.T.; MOURA, A.B.; SHAFER, J.T.; CORRÊA, B.O.; GOMES, C.B. Biocontrole da queima das bainhas e do nematoide das galhas e promoção de crescimento de plantas de arroz por rizobactérias. Pesquisa Agropecuária Brasileira, Brasília, DF, v.45, n.11, p.1259-1267, 2010. 
TAYLOR, H.L.; SASSER, J.N. Biological, identification and control of root-knot nematodes (Meloidogyne sp.). Raleigh: North Carolina State University Graphics, 1978. p. 111 .

TKACHENKO, O.V.; EVSEEVA, N.V.; BOIKOVA, N.V.; MATORA, L.Y.; GENNADY, L.B.; LOBACHEV, Y.V.; SHCHYOGOLEV, S.Y. Improved potato microclonal reproduction with the plantgrowthpromoting rhizobacteria Azospirillum. Agronomy for Sustainable Development, Paris, v.35, n.3, p.1167$1174,2017$.

XIANG, N.; LAWRENCE, K.S.; KLOEPPER, J.W.; DONALD, P.A.; MCINROY, J.A.; LAWRENCE, G.W. Biological control of Meloidogyne incognita by sporeforming plant growth-promoting rhizobacteria on cotton. Plant Disease, Saint Paul, v.101, n.5, p.774-784, 2017.
ZAHID, M.; ABBASI, M.K.; HAMEED, S.; RAHIM, $\mathrm{N}$. Isolation and identification of indigenous plant growth promoting rhizobacteria from Himalayan region of Kashmir and their effect on improving growth and nutrient contents of maize (Zea mays L.). Frontiers in Microbiology, Richland, v.6, n.207, p.1-11, 2015. 